\title{
Association between the phenotype of the blood group system ABO and Leukemia.
}

\author{
Perla Patricia Ochoa-García ${ }^{1}$, Aurora Martínez-Romero ${ }^{1 *}$, Sandra Isabel Hernández-González ${ }^{1}$, Luis \\ Otoniel García-Contreras ${ }^{1}$, José Luis Ortega-Sánchez², José Ramón Hernandez-Salgado², Maribel \\ Cervantes-Flores ${ }^{3}$
}

${ }^{1}$ Facultad de Ciencias Químicas, Campus Gómez Palacio, Universidad Juárez del Estado de Durango, México

${ }^{2}$ Unidad Regional Universitaria de Zonas Áridas. Universidad Autónoma Chapingo. Bermejillo, Durango, México

${ }^{3}$ Facultad de Ciencias Químicas, Campus Durango, Universidad Juárez del Estado de Durango, México

\begin{abstract}
The AB0 system has been established as a risk factor or protection associated with the development of multiple pathologies. Thus, the search continues for its association with other diseases. The objective of this study was to determine the association between the ABO blood system and leukemias. Blood samples were obtained from 102 patients with a presumptive diagnosis of leukemia. We carried out an AB0 typification with Gel-cards. The morphological classification of leukemia was based on the identification of the cellular line and its differentiation stage by means of a peripheral blood smear with Wright staining. The statistical analysis was performed with SAS/STAT ${ }^{\circledR}$ ver. 9.2 statistical software. The X2Pearson test was utilized for determining the association between two variables. An association was found of $\mathrm{ABO}$ blood groups and leukemias of acute presentation, reporting more cases of those expected for AML in patients with AB blood group and a greater proportion of ALL in those with blood groups $A, B$, and 0 [X2.-Pearson $=102 ; \mathrm{df}=3 ; p=0.001]$. More cases were reported than those expected of $\mathrm{CML}$ in patients with blood groups $B$ and CLL than in persons of group 0 [X2-Pearson=6.604; $d f=1 ; p=0.017]$. According to age group, an association was found of pediatric patients with ALL and adult patients with CLL (X2-Pearson=8.860; $\mathrm{df}=3 ; \mathrm{p}=\mathbf{0 . 0 3}$ ). According to the study, the AB0 blood system is associated with leukemias of acute presentation.
\end{abstract}

Keywords: Rh, Acute lymphoblastic leukemia, Chronic lymphocytic leukemia, AB0 blood group.

Accepted on June 21, 2019

\section{Introduction}

Karl Landsteiner, in the XX century, demonstrated the existence of antigenic particles in the membrane of the erythrocyte, developing the knowledge of the AB0 system. The antigens of the $\mathrm{AB} 0$ blood group are the most frequently studied genetic markers in large groups of persons. The antigens are expressed on the surface of the red blood cells and in a variety of cells and human tissues [1]. There are four common blood groups in the $\mathrm{AB} 0$ system, $0, \mathrm{~A}, \mathrm{~B}$, and $\mathrm{AB}$, whose frequencies vary according to racial/ethnic groups. From the rise of the AB0 system, numerous investigations have focused on associating it with the development of diverse pathologies, as carried out by Allan and Dawson in 1968, finding a diminished population belonging to the 0 blood group with ischemic cardiac disease in comparison with the high number of patients with other blood groups [2]. In the same manner, Miao in 2014 reported that Caucasian women with blood group A had a greater risk of developing breast cancer [3]; clearly, the AB0 blood groups provide a special vulnerability to those who possess a specific blood group [4]. From this association arises the need to investigate the relationship of the AB0 system with other types of cancer, such as leukemia. The term leukemia (Leukämie) signifies "white blood" (from the Greek leuco, $\lambda \varepsilon v \kappa o ́ s: ~ " w h i t e " ~ a n d ~ e m i a, ~ \alpha \tilde{\mu} \mu \alpha$ : "blood"). Currently, leukemia is defined as a heterogeneous group of hematological cancers that predominantly affect the peripheral blood and the bone marrow. The disease is classified into four groups: Acute Myeloid Leukemia (AML); Acute Lymphoblastic Leukemia (ALL); Chronic Myeloid Leukemia (CML), and Chronic Lymphocytic Leukemia (CLL) [5]. ALL constitutes $25 \%$ of all types of cancer, representing between 0.5 and $3 \%$ of all malignant neoplasms worldwide, being in 2019 the eleventh most common cancer in the world [6]. In ALL, the blasts are homogeneous, the nucleus is regular, the chromatin is homogeneous, small, or nulolytic, with scarce cytoplasm and slight-to-moderate basophilia [7]. CLL is the most common type of chronic leukemia in the greater part of Western countries, and it is the most common leukemia in adults, representing nearly $25 \%$ of all leukemias and $1.3 \%$ of 
all cancers [8]. CML is a rare entity in Pediatrics, corresponding to $3-5 \%$ of all leukemias. The behavior of the final phase of the disease is similar to that of acute leukemia: $60-70 \%$ of cases have myeloblastic morphology and one third, lymphoblastic [9]. AML is the most frequent myeloid disorder and it is characterized by a clonal disorder of hematopoietic cells [10]; it can infiltrate nearly all of the systemic organs, including the heart [11], and is responsible for $20-30 \%$ of leukemia-associated mortality at pediatric age. In AML, the morphology of the erythrocytes in the peripheral blood changes to an enormous degree, with cystocytes, "brush-stroke" cells or fungus-shaped cells, echinocyte cells, and spiculated acanthocytes [7]. The leukemic cells impede the production of red blood cells, platelets, and healthy leukocytes. Therefore, it is important to determine novel factors that could be associated with the development of these diseases in order to facilitate their diagnosis and prevention in populations susceptible to developing them. The results of this study could be utilized by the health authorities to implement measures that could contribute to strengthening care programs for neoplasms. The objective of this study was to determine the association between the AB0 blood group and leukemias.

\section{Material and Methods}

The study was approved by the Hospital General de Lerdo Committee of Ethics in Investigation registered with number 000374 and was conducted according to the principles of the Declaration of Helsinki. Signed informed consent was collected in written form from each participant prior to the study. Blood samples were obtained from 102 patients with a presumptive diagnosis of leukemia during their hospitalization period, at UMAE-IMSS 71, from January 2018 to December 2018. The DG-Gel cards (Licon, México) were employed for AB0 typification according to the technique described by Lapierre et al. [12] reported agglutination reactions in red blood cells. The morphological classification of leukemia was based on the identification of the cellular line and its differentiation stage according to the French-American-British (FAB) sub-classification by means of smears with Wright stain.

\section{Statistical analysis}

Statistical analysis was performed with SAS/STAT ${ }^{\circledR}$ ver. 9.2 statistical software (2nd edition) (SAS Institute, Inc., Cary, NC, USA). Frequencies or mean values are reported as descriptive statistics. Chi-square-Pearson test was utilized to determine the association between two variables and a 95\% Confidence Interval $(95 \% \mathrm{CI})$ was considered. The $\mathrm{p}$ value of less than 0.05 was considered statistically significant.

\section{Results}

Of a total of 102 patients with a presumptive diagnosis of leukemia; $63 \%(n=64)$ were adults aged $18-71$ years and there were $37 \%(n=38)$ pediatric patients aged 2-17 years, in whom the phenotype of the AB0 blood group system was determined. A distribution was obtained of 0 of $68.66 \%(n=70)$, A $16.66 \%$ $(n=17), B 12.72 \%(n=13)$, and AB $1.96 \%(n=2)$. For the phenotypes of the Rh system, a distribution of $\mathrm{Rh} D 98.03 \%$ $(\mathrm{n}=100)$ and $\mathrm{Rh} \mathrm{d} 1.97 \%(\mathrm{n}=2)$. No significant difference was found for the distributions of the AB0 blood groups between adult and pediatric patients (Table 1).

Table 1. Frequencies of phenotypes $A B O$ and $R h$.

\begin{tabular}{|c|c|c|c|c|}
\hline Phenotype & $\begin{array}{l}\text { Adult patients } \\
18-71 \text { years of age } \\
(n=64) \\
n / \%\end{array}$ & $\begin{array}{l}\text { Pediatric patients } \\
\text { aged 2-17 years } \\
(n=38) \\
n / \%\end{array}$ & $\begin{array}{l}\text { Adult } \\
\text { vs. pediatric patients } \\
\text { p }^{*}\end{array}$ & $\begin{array}{l}\text { Total } \\
\text { Frequencies/\% }\end{array}$ \\
\hline (I) & Phenotype AB0 & & & \\
\hline $\mathrm{O}$ & $47 / 73.45$ & $23 / 60.54$ & 0.635 & $70 / 68.66$ \\
\hline A & 9/14.06 & $8 / 21.05$ & 0.7 & $17 / 16.66$ \\
\hline B & $7 / 10.93$ & $6 / 15.78$ & 0.463 & $13 / 12.72$ \\
\hline$A B$ & $1 / 1.56$ & $1 / 2.63$ & 0.1 & $2 / 1.96$ \\
\hline (II) & Phenotype Rh & & & \\
\hline Rh D & $63 / 98.44$ & $37 / 97.37$ & 0.26 & $100 / 98.03$ \\
\hline $\mathrm{Rh} d$ & $1 / 1.56$ & $1 / 2.63$ & 0.1 & $2 / 1.97$ \\
\hline
\end{tabular}

${ }^{*} \mathrm{p}<0.05 ; \mathrm{X} 2-$ Pearson

In adult patients, a greater frequency was found of $\mathrm{ALL}>\mathrm{AML}>\mathrm{CML}>\mathrm{CLL}$, while in pediatric patients, more cases presented of ALL $>$ AML $>$ CML. According to the age groups, pediatric patients aged 0-17 years were associated with 
ALL and adult patients aged 18-71 years were associated with CLL (Table 2).

Table 2. Frequencies of leukemias in adult-pediatric patients.

\begin{tabular}{|c|c|c|c|c|}
\hline Type of leukemia & $\begin{array}{l}\text { Adult patients } \\
\text { aged 18-71 years } \\
(n=64)\end{array}$ & $\begin{array}{l}\text { Pediatric patients aged } \\
2-17 \text { years } \\
(n=38)\end{array}$ & $\begin{array}{l}\text { Adult patients vs. } \\
\text { pediatric } \\
\text { patients }\end{array}$ & $\begin{array}{l}\text { Total } \\
\mathrm{n} / \%\end{array}$ \\
\hline & $n / \%$ & $n / \%$ & $\mathbf{p}^{*}$ & \\
\hline ALL & $28 / 43.76$ & $23 / 60.53$ & $0.035^{\star}$ & $51 / 50$ \\
\hline AML & $24 / 37.5$ & $11 / 28.95$ & 0.604 & $35 / 34.31$ \\
\hline CML & $9 / 14.06$ & $4 / 10.52$ & 0.333 & $13 / 12.75$ \\
\hline CLL & $3 / 4.68$ & $0 / 0$ & $0.035^{*}$ & $3 / 2.94$ \\
\hline
\end{tabular}

${ }^{*} \mathrm{p}<0.05 ; \mathrm{X} 2-\mathrm{Pearson}$

Among the patients of the 0-blood group, cases were found of ALL $>$ AML $>$ CML $>C L L$. In terms of patients belonging to the $\mathrm{B}$ blood group, three types of leukemia presented: ALL $>$ AML $>$ CML. Only two types of leukemia were observed in patients with blood group A: ALL, and ALL. However, solely one type of leukemia was reported: in blood group AB. Significant differences were found for the association of $\mathrm{AB} 0$ blood groups and leukemias of acute presentation, reporting more cases than expected for AML in patients with $\mathrm{AB}$ blood group and a greater proportion of ALL in those with blood groups $\mathrm{A}, \mathrm{B}$, and 0 [X2-Pearson test $=102 ; \mathrm{df}=3 ; \mathrm{p}=0.001]$. Likewise, more cases than expected were reported of CML in patients with blood group B and of CLL in persons with LLC with blood group 0 [X2-Pearson test $=5.60 ; \mathrm{df}=1 ; \mathrm{p}=0.017]$ (Table 3).

Table 3. Leukemias in ABO blood groups.

\begin{tabular}{|c|c|c|c|c|c|}
\hline Type of leukemia & $\begin{array}{l}\text { Blood group A } \\
n / \%\end{array}$ & $\begin{array}{l}\text { Blood group AB } \\
n / \%\end{array}$ & $\begin{array}{l}\text { Blood group B } \\
n / \%\end{array}$ & $\begin{array}{l}\text { Blood group } 0 \\
n / \%\end{array}$ & $\begin{array}{l}\text { Total } \\
\mathrm{n} / \%\end{array}$ \\
\hline ALL & $9 / 53$ * & $0 / 0$ & $6 / 46$ * & $36 / 51$ * & $51 / 50$ \\
\hline AML & 17380 & $2 / 100$ * & 11414 & $21 / 30$ & $35 / 34$ \\
\hline CML & $0 / 0$ & $0 / 0$ & $3 / 23$ * & 41913 & $13 / 13$ \\
\hline CLL & $0 / 0$ & $0 / 0$ & $0 / 0$ & $3 / 5$ * & 43527 \\
\hline
\end{tabular}

Among adult patients of the 0-blood group were found cases of ALL 48.93\% ( $\mathrm{n}=23)$, AML 31.91\% ( $\mathrm{n}=15)$, CML 12.76\% $(n=6)$, and CLL LLC $6.38 \%(n=3)$. With respect to patients belonging to blood group $\mathrm{B}$, these presented three types of leukemia: LMA 42.85\% $(n=3)$; CML 42.85\% $(n=3)$, and ALL $14.28 \%(n=1)$. Only two types of leukemia were observed in patients of the A blood group: AML 55.55\% $(n=5)$ and ALL $44.44 \%(n=4)$. However, a sole type of leukemia was reported, that is, AML $100 \%(n=1)$ in persons with blood group AB.

In pediatric patients of the 0 blood group, we found leukemias ALL 52\% $(n=13)$, AML 24\% $(n=6)$, and CML 17.39\% $(n=4)$, while within the B blood group, two types of leukemias were reported: ALL 83.33\% $(n=5)$ and AML 16.66\% $(n=1)$. In a similar manner, in pediatric patients with A blood groups, cases presented of ALL $62.5 \%(n=5)$ and AML 37.5\% $(n=3)$. In contrast, only one case was found of AML $100 \%(n=1)$ in patients of the $\mathrm{AB}$ blood group. Significant differences were not found for the association of leukemias and blood groups by age group (Table 4).

\section{Discussion and Conclusion}

The distribution of the AB0 system has been widely studied worldwide, yielding a great variety of results. However, despite this variation, blood group 0 has been reported as the most frequent in as great part of these studies, being the most common blood group in Latin populations. In contrast, the $\mathrm{AB}$ blood group has continually been described as the least frequent in the majority of human populations $[13,14]$. In this study, we found a distribution $\mathrm{O}>\mathrm{A}>\mathrm{B}>\mathrm{AB}$, blood groups coinciding with the distributions reported in studies conducted in Mexico [15,16]; similarly, they coincide with distributions reported in populations of Nigeria and Iraq [13,17], contrasting slightly with studies performed in Latin populations of other countries, where distributions are reported of $\mathrm{A}>0>\mathrm{B}>\mathrm{AB}$ [18]. This difference can be attributed to the different sample sizes 
employed in the studies, in addition to the miscegenation proper to each country.

Table 4. Leukemias in ABO blood groups of adult and pediatric patients.

\begin{tabular}{|c|c|c|c|c|c|}
\hline Type of leukemia & $\begin{array}{l}\text { Blood group A } \\
n \%\end{array}$ & $\begin{array}{l}\text { Blood group } A B \\
n \%\end{array}$ & $\begin{array}{l}\text { Blood group B } \\
n \%\end{array}$ & $\begin{array}{l}\text { Blood group } 0 \\
n \%\end{array}$ & $\begin{array}{l}\text { Total } \\
n \%\end{array}$ \\
\hline \multicolumn{6}{|l|}{ Adult patients } \\
\hline ALL & $4 / 44.44$ & $0 / 0$ & $1 / 14.28$ & $23 / 48.93$ & $28 / 44$ \\
\hline AML & $5 / 55.55$ & $1 / 100$ & $3 / 42.85$ & $15 / 31.91$ & $24 / 38$ \\
\hline CML & $0 / 0$ & $0 / 0$ & $3 / 42.85$ & $6 / 12.76$ & 41883 \\
\hline CLL & $0 / 0$ & $0 / 0$ & $0 / 0$ & $3 / 6.38$ & 43558 \\
\hline \multicolumn{6}{|l|}{ Pediatric patients } \\
\hline ALL & $5 / 62.5$ & $0 / 0$ & $5 / 83.33$ & $13 / 52$ & $23 / 60$ \\
\hline AML & $3 / 37.5$ & $1 / 100$ & $1 / 16.66$ & 45444 & 47423 \\
\hline CML & $0 / 0$ & $0 / 0$ & $0 / 0$ & $4 / 17.39$ & 43773 \\
\hline CLL & $0 / 0$ & $0 / 0$ & $0 / 0$ & $0 / 0$ & $0 / 0$ \\
\hline
\end{tabular}

${ }^{*} \mathrm{p}<0.05 ; \mathrm{X} 2$-Pearson.

In the present investigation, a greater frequency was reported of patients with ALL; likewise, an association was found of patients with ALL, as well as an association of pediatric patients aged 0-17 years with ALL, which can be due to that this disorder constitutes $25 \%$ of all types of cancer, being the most frequent childhood cancer type [19]. Later, cases were found of ALL that tend to be the most common myeloid affliction [10], proliferating above all in adult patients. Despite this, it is in general sufficiently infrequent, representing only $1 \%$ of all cancers [20]. In the ambit of chronic leukemias, few cases of CML were detected, whose low frequency can be due to its being a scarcely common affliction, representing 3-5\% of leukemias [9]. In this instance, only three cases of CLL were detected that were associated in the 8-71 years-of-age group. Despite its low incidence in the present study, it tends to be the most frequent type of chronic leukemia in the greater part of Western countries and is the most common leukemia in adults, representing nearly $25 \%$ of all leukemias and $1.3 \%$ of all cancers [8]. The scarce presence of CLL can be associated with the age range of the patients participating on this study, in that CLL tends to present at around 64 years of age, and nearly one half of the cases are diagnosed in persons aged older than 65 years [21,22], an aspect with which very few of the participants complied. Despite the very few epidemiological studies related with leukemia carried out in Mexico, our results coincide with that reported by Santoyo-Sánchez et al. (2016) in a study population of the Valley of Mexico [23].

Associations were obtained for AML in patients with the $\mathrm{AB}$ blood group and a greater proportion of ALL in those with the A, B, and 0 blood groups. Similarly, more cases were reported that expected of CML in patients with blood groups $\mathrm{B}$ and CLL in persons with blood group 0 , as reported by Wolpin and collaborators (2010), Iavarone et al. (2016), Akin and collaborators (2018), and Stakisaitis et al. (2018) with other types of localized cancer [24-27]. In this regard, this investigation is added to all of those in which were found an association of the AB0 blood system with different pathologies, such as cardiovascular disease, familial hypercholesterolemia, and hepatitis $\mathrm{B}$ virus infection, or a worse diagnosis in diseases such as urothelial carcinoma of the gall bladder [14,28-30], on contrasting our results with those of investigations that did not report an association of the AB0 system with pathologies such as nasal polyposis, endometriosis, and osteoporosis [4,31-33]. The clinical importance of the systems of blood groups currently extends beyond Transfusional Medicine. Therefore, it is imperative to investigate the mechanisms by which the $\mathrm{AB} 0$ system is associated with different pathologies. In conclusion, our study demonstrated an association between the phenotypes of the AB0 blood system and leukemias; the ABO blood system is associated with leukemias of acute presentation. Due to that the frequencies of $\mathrm{AB} 0$ blood groups and leukemias vary from one population to another, it would be interesting to see results of similar studies conducted in regions with different $\mathrm{AB} 0$ groups.

\section{References}

1. Alkebsi L, Ideno Y, Lee JS, Suzuki S, Nakajima-Shimada J, Ohnishi H, Sato Y, and Hayashi K. Gastroduodenal ulcers and ABO blood group: the Japan Nurses' Health Study (JNHS). J Epidemiol 2018; 28: 34-40.

2. Allan A, Dawson A. AB0 blood groups and ischaemic heart disease in men. Br Heart J 1968; 30: 377-82.

3. Miao SY, Zhou W, Chen L, Wang S, and Liu XA. Influence of ABO blood group and Rhesus factor on breast cancer risk: a meta-analysis of 9665 breast cancer patients and 
244,768 controls. Asia-Pacific J Clin Oncol 2014; 10 : 101-8.

4. Seyfizadeh N, Seyfizadeh N, Negahdar H, Hosseini SR, Nooreddini H, and Parsian H. AB0 blood group and prevalence of osteoporosis and osteopenia in the elderly population: an Amirkola Health and Ageing Project (AHAP)-based study. J Clin Densitom 2018; 21: 200-4.

5. Kouhpeikar H, Butler AE, Bamian F, Barreto GE, Majeed $\mathrm{M}$, and Sahebkar A. Curcumin as a therapeutic agent in leukemia. J Cell Physiol 2019; 234: 12404-14.

6. Yousef AM, Farhad R, Alshamaseen D, Alsheikh A, Zawiah $M$, and Kadi T. Folate pathway genetic polymorphisms modulate methotrexate-induced toxicity in childhood acute lymphoblastic leukemia. Cancer Chemoth Pharm 2019; 83: 755-62.

7. Ladines-Castro W, Barragán-Ibáñez G, Luna-Pérez MA, Santoyo-Sánchez A, Collazo-Jaloma J, Mendoza-García E, and Ramos-Peñafiel CO. Morphology of leukaemias. Rev Med Hosp Gen Mex 2016; 79: 107-13.

8. Strati P, Jain N, and O'Brien S. Chronic lymphocytic leukemia: diagnosis and treatment. Mayo Clin Proc 2018; 93: 651-64.

9. Morales-Peralta A, Covarrubias-Espinoza G, ArvizúAmador T, Rendón-García H, Larios-Farak T, and Martínez-González A. Leucemia mieloide crónica con transformación basofílica: presentación de un caso. Bol Clin Hosp Infant Edo Son 2015; 32: 44-8.

10. Hu T, Li C, Zhang Y, Wang L, Peng L, Cheng H, Wang W, Chu Y, Xu M, Cheng T and Yuan W. Phosphoinositidedependent kinase 1 regulates leukemia stem cell maintenance in MLL-AF9-induced murine acute myeloid leukemia. Biochem Bioph Res Co 2015; 459: 692-8.

11. Agrawal K, Miles L, Agrawal N, and Khan A. Atypical presentation of acute myeloid leukemia. World J Oncol 2018; 9: 29-34.

12. Lapierre Y, Rigal D, Adam J, Josef D, Meyer F, Greber S, and Drot C. The gel test: a new way to detect red cell antigen-antibody reactions. Transfusion 1990; 30: 109-13.

13. Jaff MS. AB0 and Rhesus blood group distribution in Kurds. J Blood Med 2010; 1: 143-6.

14. Liu J, Zhang S, Liu M, Wang Q, Shen H, and Zhang Y. Distribution of $\mathrm{AB} 0 / \mathrm{Rh}$ blood groups and their association with hepatitis $\mathrm{B}$ virus infection in 3.8 million Chinese adults: a population-based cross-sectional study. J Viral Hepatitis 2018; 25: 401-11.

15. Del Peón-Hidalgo L, Pacheco-Cano MG, Zavala-Ruiz M, Madueño-López A, and García-González A. [Blood group frequencies and $\mathrm{AB} 0$ and $\mathrm{RhD}$ incompatibilities in La Paz, Baja California Sur, Mexico]. Salud Publica Mex 2002; 44: 406-12.

16. Iturbe Chiñas $P$, Jimeánez Hernández J, Peralta Ortega D, and Toribio Jiménez J. Frecuencias de grupos sanguíneos AB0, Rh y grado de mestizaje en la Región Montaña, Guerrero, México. Rev Med Hosp Gen Mex 2013; 76: 217-23.
17. Anifowoshe AT, Owolodun OA, Akinseye KM, Ajibola Iyiola OA, and Oyeyemi BF. Gene frequencies of AB0 and Rh blood groups in Nigeria: a review. Egypt J Med Hum Genet 2017; 18: 205-10.

18. Causil-Vargas L, Gómez-Mercado L, Otero-Díaz D, Moscote-Blanco L, Monterrosa-Mestra L, Burgos-Flórez D, and Herrera-Benavides Y. Frecuencia de grupos sanguíneos (Sistema AB0) entre estudiantes de la Universidad de Córdoba sede Berástegui. CIMEL 2016; 21: 24-7.

19. Hernández Estrada MM, Haro Acosta ME, Hurtado Llamas RM, Ortega Vélez G, and Barreras Serrano A. Causas de mortalidad por leucemia linfoblástica en niños del Instituto Mexicano del Seguro Social. El Residente 2017; 12: 44-7.

20. https://www.cancer.org/es/cancer/leucemia-mieloide-aguda/ acerca/estadisticas-clave.html

21. Árias Segura JO, Valero González JM. Leucemia linfocítica crónica. Lux Médica 2013; 25: 29-38.

22. https://www.cancer.org/es/cancer/leucemia-linfociticacronica/acerca/estadisticas-clave.html

23. Santoyo Sánchez A, Ramos Peñafiel CO, Saavedra González A, González Almanza L, Martínez Tovar A, Olarte Carrillo I, and Collazo-Jaloma J. Frecuencias de edad y género de pacientes con leucemia observada en dos centros de referencia del Valle de México. Gac Med Mex 2016; 152: 208-12.

24. Wolpin BM, Kraft P, Gross M, Helzlsouer K, Bueno-deMesquita HB, Steplowski E, Stolzenberg-Solomon RZ, Arslan AA, Jacobs EJ, Lacroix A, Petersen G, Zheng W, Albanes D, Allen NE, Amundadottir L, Anderson G, Boutron-Ruault MC, Buring JE, Canzian F, Chanock SJ, Clipp S, Gaziano JM, Giovannucci EL, Hallmans G, Hankinson SE, Hoover RN, Hunter DJ, Hutchinson A, Jacobs K, Kooperberg C, Lynch SM, Mendelsohn JB, Michaud DS, Overvad K, Patel AV, Rajkovic A, Sanchéz MJ, Shu XO, Slimani N, Thomas G, Tobias GS, Trichopoulos D, Vineis P, Virtamo J, Wactawski-Wende J, Yu K, Zeleniuch-Jacquotte A, Hartge P, and Fuchs CS. Pancreatic cancer risk and AB0 blood group alleles: results from the Pancreatic Cancer Cohort Consortium. Cancer Res 2010; 70: 1015-23.

25. Iavarone M, Della Corte C, Pelucchi C, Marconi M, Trotti R, Triolo M, Manini MA, and La Vecchia C. Risk of hepatocellular carcinoma in relation to AB0 blood type. Digest Liver Dis 2016; 48: 94-6.

26. Stakišaitis D, Juknevičienè M, Ulys A, Žaliūnienė D, Stanislovaitienė D, Šepetienė R, Slavinska A, Sužiedèlis K, and Lesauskaite V. AB0 blood group polymorphism has an impact on prostate, kidney and bladder cancer in association with longevity. Oncol Lett 2018;16: 1321-31.

27. Akin S, Altundag K. Clinical associations with AB0 blood group and Rhesus blood group status in patients with Breast cancer: a nationwide retrospective study of 3,944 breast cancer patients in Turkey. Med Sci Monit 2018; 24: 4698-703. 
28. Bronte-Stewart B, Botha MC, and Krut LH. AB0 blood groups in relation to ischaemic heart disease. $\mathrm{Br}$ Med J 1962; 1: 1646-50.

29. Paquette M, Dufour R, and Baass A. AB0 blood group is a cardiovascular risk factor in patients with familial hypercholesterolemia. J Clin Lipidol 2017; 12: 383-9.

30. Klatte T, Xylinas E, Rieken M, Rouprêt M, Fajkovic H, Seitz C, Karakiewicz PI, Lotan Y, Babjuk M, de Martino $\mathrm{M}$, and Shariat SF. Effect of AB0 blood type on mortality in patients with urothelial carcinoma of the bladder treated with radical cystectomy. Urol Oncol-Semin Ori 2014; 32: 625-30.

31. Jelavic B, Markovic J, Klaric S, Martinac M, Selak S, and Baudoin T. AB0 and RhD blood groups in nasal polyposis. Turk Arch Otorhinolaryngol 2018; 56: 21-4.

32. Malekzadeh F, Moini A, Amirchaghmaghi E, Daliri L, Akhoond MR, Talebi M, and Hosseini R. The association between $\mathrm{AB} 0$ and $\mathrm{Rh}$ blood groups and risk of endometriosis in iranian women. Int J Fertil Steril 2018; 12: 213-7.

33. Lin K, Qiu F, Chen S, He X, Peng S, and Chen H. Lack of association between the distribution of AB0 blood groups and nasopharyngeal carcinoma in a population of Southern China. J Can Res Ther 2018; 14: 785-8.

\section{*Correspondence to}

Aurora Martinez-Romero

Facultad de Ciencias Químicas

Campus Gómez Palacio

Universidad Juárez del Estado de Durango

México 